Medby, I.A. (2018) 'Articulating state identity: 'Peopling' the Arctic state', Political Geography 62, pp. 116 -

125, DOI: $10.1016 /$ j.polgeo.2017.10.008.

\title{
ARTICULATING STATE IDENTITY: 'PEOPLING' THE ARCTIC STATE
}

\section{Introduction}

You come from a certain place, and you are influenced when you grow up and when you live here. You are

influenced by media of course, and by nature, and by just being here. [...] When you become a politician, you are

a person with your experience and your education; of course you put it all together and you reflect what you are.

You can't be anything else. So, I think that, yeah, your identity and who you are and what you are, it [influences]

how you play the politics and your views on the world, of course (Icelandic politician, 2014).

The "certain place" the above politician was referring to is the Arctic state of Iceland, as she reflected on how her own sense identity influences her everyday work. As she makes clear, her identity is not only derived from what takes place between office walls, nine to five. It is about childhood, experiences, education, media, and nature, to mention but some factors. It is about the influence of "just being here". Representing an Arctic state, all of these influences play their part, big or small; in her words, “you can't be anything else". However, it is only recently that the Arctic region has been publicly re-articulated as anything but distant, exotic, and even threatening, far from the imagined "homeland" of the eight Arctic states. With Arctic climate change and international interest, narratives of identity are being told and re-told, interpreted in light of a new geopolitical context: it is not about owning the Arctic, but about being Arctic. 
Medby, I.A. (2018) 'Articulating state identity: 'Peopling' the Arctic state', Political Geography 62, pp. 116 -

125, DOI: $10.1016 /$ j.polgeo.2017.10.008.

Despite today's recognition of global interconnectedness, both in terms of socio-political globalisation and climate change, the idea(l) of "nation-states" and national identities seem as strong as ever. Political geographers have in recent years directed attention to some of these seemingly paradoxical developments: to the powerful persistence of national identities (e.g. Antonsich, 2009; Closs Stephens, 2013; Matejskova and Antonsich, 2015), and to the re-structuring and re-imagining of statehood (e.g. Brenner, 2004; Moisio and Paasi, 2013a, 2013b). Alongside this, a welcome contribution to geographical scholarship has been increasing interest in the influence of emotion, affect, and embodiment (e.g. Harrison, 2000; Hyndman, 2004; Anderson, 2009; Closs Stephens, 2015; Merriman and Jones, 2016). Indeed, it is increasingly recognised how politics is as much about the everyday (Jones and Merriman, 2009; Benwell and Dodds, 2011; Benwell, 2014); "the state" only ever comes about through the many and diverse practices that materialise it in the world (Abrams, 1988; Mitchell, 1991; Painter, 2006). And finally, with the recognition of the importance of practices and performances, more attention has been given to how concepts of political geography, such as the state and territory, cannot be understood without reference to the people performing and enacting them too (e.g. Jones, 2007, 2012, Kuus, 2008, 2014, 2015; Antonsich, 2011).

Despite these welcome contributions towards "peopling" political geography, what has so far received less attention is how ideas of identity and community permeate among those tasked with enacting the state on a daily basis. It is here the present paper seeks to make a contribution: bringing together literatures on identity politics, nationalism, and emotion, on the one hand; and on the other, statehood, statecraft, and (geo)political practice. In short, the paper asks how discourses of state identity are articulated by its personnel: What does it mean to "be" or represent an Arctic state; and how do identity discourses permeate 
Medby, I.A. (2018) 'Articulating state identity: 'Peopling' the Arctic state', Political Geography 62, pp. 116 -

125, DOI: $10.1016 /$ j.polgeo.2017.10.008.

among those tasked with the state's enactment on a daily basis? In so doing, it demonstrates how geographical and historical framings of identity are coupled with, understood through, and mediated by social and political relations. Hence, looking not at the effect of practices, but for the practitioners, it asks how they understand their own role and identity as Arctic state representatives. By focusing on state personnel, it allows us to explore how identity is understood as something not only to be but to do, not only to have but as something to represent - and a duty to do so well.

The specific focus here is on three of the eight formally titled Arctic states: Norway, Iceland, and Canada. It is an international region that is rapidly changing environmentally and geopolitically, and as noted, so too are narratives of identities connected thereto. Official statements in all three states have centred on the connections between their Arctic identities and statehood. However, Arctic state official or not, how do you articulate identity in relation to a space in flux, may never have been or go to, may only see on maps and TV screens? Here, what used to be global peripherality has now become centrality, and a re-interpretation of identities past, present, and future is taking place. What becomes clear from respondents' articulations below, however, is that discourses of state identity are articulated not only within the frames of geography and history, but also across relations - through the international, national, sub-national, and even personal. Relations and attachments that are intimately intertwined, all aspects of a state identity come to depend on the others in the enactment of the state, as explained in the opening quote. Hence, this paper argues that to understand Arctic states and statecraft, there is a need to acknowledge their numerous personnel, and to acknowledge their sense of identity, of self and community too. Only by listening to their articulations of 
Medby, I.A. (2018) 'Articulating state identity: 'Peopling' the Arctic state', Political Geography 62, pp. 116-

125, DOI: $10.1016 /$ j.polgeo.2017.10.008.

identity through Arctic geographies, histories, and most perhaps importantly, relations may we approach the crucial question of "how you play the politics".

In the remainder of the text, the above points are developed in three stages: Firstly, the concept of state identity discourses is situated in a wider body of scholarship on statehood and practices, national identity, and the impetus to "people" geopolitical conceptualisations. Secondly, a brief discussion of the Arctic and its current geopolitical context is offered. And thirdly, the conceptual framework is given empirical reality through the articulations of state officials in the three Arctic states Norway, Iceland, and Canada. These demonstrate how, in brief, state identity discourses are shown to be spatially and temporally bounded, but nevertheless flowing in, through, and beyond relations at all scales of interaction. State identity - Arctic or otherwise - is ever becoming anew in encounters; the way in which the state comes into being is not just political action but inter-action. With that, the paper closes with a call for more engagement, more active relating, and more attention to the highly diverse and heterogenous practitioners behind state practices.

\section{A Conceptual Framework of State Identity}

Before turning to higher latitudes, however, critically interrogating the intersections of statehood and identity is as relevant as ever. In so doing, this section starts outlining the conceptual framework of state identity discourses. Firstly positioning the present paper in current political geographical scholarship, and 
Medby, I.A. (2018) 'Articulating state identity: 'Peopling' the Arctic state', Political Geography 62, pp. 116 -

125, DOI: $10.1016 /$ j.polgeo.2017.10.008.

secondly clarifying conceptual terminology, it presents a framework that subsequently orders empirical discussion.

\section{The state: effects, practices, people}

Although it might have seemed an anachronistic endeavour to study the state and national identity no more than a couple of decades ago (see e.g. Ohmae, 1990; Fukuyama, 1992), recent events have highlighted their powerful persistence to date. One need not look far for examples of how ideas of state sovereignty, nation(alism), borders, and territories are anything but obsolete in the discursive ordering of political and social relations across the world: the so-called European migrant crisis, referenda on both EU- and UKmemberships, and promises of walls for "Great"-ness are all cases-in-point. In the Arctic region too, these events reverberate and, importantly, are met with state-level responses. A "globally embedded Arctic" or not (Keil and Knecht, 2017b), statehood still matters. Restructured, re-imagined, and re-invented perhaps (e.g. Sassen, 1996, 2013; Brenner, 2004; Moisio and Paasi, 2013a, 2013b), the state is nevertheless tied to powerful ideas of identity and belonging (see e.g. Closs Stephens, 2013; Matejskova and Antonsich, 2015). Hence, it is arguably paramount to (re)turn our analytical gaze towards the state, but with a much expanded understanding: one that forces us to consider its persistence as a locus for not only capitalised "Politics" but also belonging and safety (see Painter and Jeffrey, 2009; Closs Stephens, 2013, 2015).

Two broad developments in contemporary political geography are here of particular relevance, situating the present study. First, as critical geographers have shifted attention away from only the high echelons of government, they have shown how politics is about so much more: It is about the mundane, everyday, and 
Medby, I.A. (2018) 'Articulating state identity: 'Peopling' the Arctic state', Political Geography 62, pp. 116 -

125, DOI: $10.1016 /$ j.polgeo.2017.10.008.

prosaic (e.g. Edensor, 2002; Chatterjee, 2004; Painter, 2006; Bratsis, 2007; Jones and Merriman, 2009;

Benwell and Dodds, 2011; Benwell, 2014; Jones and Clark, 2015; Kuus, 2016); and a matter of emotion, affect, and embodiment too (e.g. Pain, 2009; Sharp, 2009; Closs Stephens, 2015; Merriman and Jones, 2016; Pykett, Jupp and Smith, 2016). Here, the influence of feminist geopolitics has been significant, as it "challenges the scales of geopolitics and refocuses on the mundane, everyday reproductions of geopolitical power" (Massaro and Williams, 2013, p. 567; see also Dowler and Sharp, 2001; Hyndman, 2004; Mountz, 2004; Dixon and Marston, 2011; Sharp, 2009).

And second, political geographers have taken up the challenge presented by e.g. Abrams (1988) and Mitchell (1991): to see the state not as an anthromorphised entity with agency in its own right, but an anthropological idea(l), which in turn takes on material reality as "the powerful, metaphysical effect of practices" (Mitchell, 1991, p. 94; see also Painter, 2006). Building on Butler's (2011) influential work, the state materialises as a result of its performance; citational, reiterative practices and statements, or here "articulations", bring it into being and give it power. What then follows is a need to interrogate how, why, and by whom these "countless mundane social and material practices" (Painter, 2006, p. 771) actively perform the state into existence. In short, there is a need to "people" the way in which we conceptualise the state. Here, the work of Merje Kuus (2008, 2014, 2015, 2016) and Rhys Jones (2007, 2012) have been particularly influential, bringing attention to the anthropological foundations of the state (see also Peck, 2001; Mountz, 2003; Sharma and Gupta, 2006; Bratsis, 2007; Jones and Clark, 2015). It is within these broad developments the present article is placed, to which it seeks to add, and from which it aims to push further in exploring Arctic state identities. 
Medby, I.A. (2018) 'Articulating state identity: 'Peopling' the Arctic state', Political Geography 62, pp. 116 -

125, DOI: $10.1016 /$ j.polgeo.2017.10.008.

\section{Discourses of State Identity}

What has so far been less explored in the above literature is how discourses of identity may influence said people of the state in their everyday and mundane tasks. It is here the present paper seeks to make a contribution: Building on work seeking to "people" political geography, pushing further towards a concept of "state identities", it asks how they understand own identity as state representatives. In other words, considering how the performance of the state idea holds traces of the state's people, who, importantly, are always more than personnel, more than elites: they, too, inhabit innumerable subject-positions that compete, overlap, intermix in their everyday actions. Rejecting a binary view of state and society (or, "political organisation" and "nation”), seeing them instead as co-dependent, could arguably also tell us more about their interaction. Indeed, recognising state personnel as members of the "imagined community" too (Anderson, 1983) might allow more dialogue, more political participation across all sectors of society, and more hope of political change. However defined, the state is no more and no less than what they, we personnel, citizens, analysts - make it, iteratively, continually, performatively (see Butler, 1999, 2011).

That is neither to suggest that state practitioners are the only actors bringing the state into being (see e.g. Scott, 1999; Corbridge, 2005; McConnell, 2009), nor to privilege "national" identities over other collective identities and imaginaries. Instead, the point is the inseparability of state and society, politics and people; the long-standing wedding of the hyphenated "nation-state" continues to provide meaning to people's lives (Sparke, 2005; Antonsich, 2009). And indeed, in scholarly eagerness to go beyond formal geopolitics to understand everyday life and people, there is risk of inadvertently reinforcing a state/society binary, where the former is assumed to successfully construct a top-down identity among the latter. Not only does this paint 
Medby, I.A. (2018) 'Articulating state identity: 'Peopling' the Arctic state', Political Geography 62, pp. 116 -

125, DOI: $10.1016 /$ j.polgeo.2017.10.008.

a caricatured picture of a population of passive subjects, readily duped and universally "affected", but also an equally caricatured government or elite, who sits above and abstracted from said everyday life (see Sharp, 1993). If identity, national or otherwise, and even nationalist ideology have become so important to some populations across the world today, who is to say this is not also the case among state employees - indeed, those whose everyday jobs rely on said idea(l)? As we will see below, in the Arctic too do these ideas hold a powerful place in people's imaginaries of self and community; and indeed, so too do they among those professionally involved therewith. Firstly, this brings together the micro and the macro, the individual and the collective, in order to highlight how they both constitute each other. And, secondly, the aim here is to foreground identities' consolidation in space and time, their spatiotemporality, thereby remaining firmly embedded in the discipline of geography, while showing its inherent relationality.

Before discussing the conceptual framework however, two points of conceptual clarification are here necessary: First, employing the term "identity" is not meant to imply that there is a singular or static essence of the "self"; rather, any individual will always represent a multitude of different, fluctuating characteristics and groupings at any given time (e.g. Jameson, 1991; Yaeger, 1996). This means that identity is always contextual, fluid, and relational; it is a process of identification through which we gain "our sense of ourselves as individuals and social beings" (Bondi, 1993, p. 86; see also Fearon, 1999) - a sense that is both deeply political and powerful (see Pile and Thrift, 1995). Hence, talking about national, or indeed state, identity is always a relational act: the articulation of subjectivity gained from performing and inhabiting innumerable subject-positions (Butler, 1999, 2011), and moving in and out of temporarily sensed collectives (Ahmed, 2004; Closs Stephens, 2015; Merriman and Jones, 2016). 
Medby, I.A. (2018) 'Articulating state identity: 'Peopling' the Arctic state', Political Geography 62, pp. 116-

125, DOI: $10.1016 /$ j.polgeo.2017.10.008.

Second, the way in which "discourses" are here understood are as the conditions for what may be meaningfully said, done, and thought, following Foucault (1972, also 2002). Always within discourses, we may only access and analyse their surfacing as "statements" broadly defined: what is said, not said, done, not done, “citing” performances past and present (Butler, 1999, 2011). And, as such, discourses are simultaneously material and abstract, and certainly not merely linguistic. Discourses both produce and are a product of practices and knowledges - interlocking, overlapping schema of meaning that order human relations (e.g. Kendall and Wickham, 1999). Discourses of (state) identity, then, do not refer as much to what subjects or collectives supposedly "are", but produce them in a process of defining boundaries based on what they are not; i.e. they are always relationally becoming (Connolly, 1991; Walker, 1993). And finally, while they may order relations, discourses are always open to change and contingency. Each and every "performer" thereof leaves a trace of their own subjectivity, always beyond and always exceeding any singularity. Hence, through relations - social and political, inside and outside offices - the "people" of the state may also change the way in which the state is performed into being.

In sum then, discourses of "state identity" refer to such identity-discourses amongst those representing the state on an everyday basis; how they understand own identity as such. In turn, these are discourses that may potentially condition the practices through which the state emerges: when state practices come to be seen as a performance of "who we are" it becomes seemingly unquestionable, an assumed transcendental "truth" not just among those represented, but also among those representing. In other words, these are discourses that are not descriptive of what/where/who the state "is", but may become part of its active making. Any 
Medby, I.A. (2018) 'Articulating state identity: 'Peopling' the Arctic state', Political Geography 62, pp. 116-

125, DOI: $10.1016 /$ j.polgeo.2017.10.008.

identity is always a positioning in space and time, geography and history; and so, these are discourses that spatially and temporally stabilise an ever evolving, abstract idea of statehood. As will become clear below, state identity discourses are therefore spatiotemporally "bounded" in their articulation. These discursive boundaries may be a delimited territory, environment, and geography (see Thongchai, 1997; Agnew, 1999; Taylor, 2003; Antonsich, 2011); and a narrative, history, and seemingly linear progression from past through present to future (see Anderson, 1983; Cameron, 2009, 2015; Crang and Tolia-Kelly, 2010). However, crucially, discourses are also always relationally constituted - and potentially contested, interrupted, changed. Discourses of state identity come about through a multitude of relations, from the international - via the regional, the national, and the sub-national - to the intimately personal. In short, the aim in what follows is to explore through the Arctic context how such discursive articulations of state identity are both spatiotemporally regulated and yet always inherently relational; how those tasked with its performance understand their own identity as such; considering Arctic political practices through the articulations of its practitioners. Questioning these discourses of state identity is in effect a questioning of taken-for-granted assumptions about who these officials consider "we are" to really question if this is, indeed, who "we" want to be; and this, in the end, is why it matters.

\section{The Changing Arctic}

\section{$\underline{\text { Arctic geopolitics and statehood }}$}

Bringing the concept of state identity discourses specifically to the Arctic, the empirical focus is not coincidental. The Arctic offers particularly fascinating stage upon which to observe the active performance 
Medby, I.A. (2018) 'Articulating state identity: 'Peopling' the Arctic state', Political Geography 62, pp. 116 -

125, DOI: $10.1016 /$ j.polgeo.2017.10.008.

of state identities. As Arctic statehood is officially defined in the most traditional sense by borders and territories (above the latitude of $66^{\circ} 33^{\prime} 39^{\prime \prime}$ ) it may at first seem to provide a highly typical ideal of sovereignty; yet, in practice rather one that proves highly a-typical. Geographically, most of the Arctic region is anything but typical state "territory": largely oceanic, fluid, frozen (for now), and at least partly uninhabited ${ }^{1}$. Today, frequently described as a space in rapid flux - environmentally and geopolitically - the Arctic thus presents a range of challenges to traditional conceptualisations of statehood, territory, and sovereignty (see Mountz, 2013). Yet, paradoxically, it is simultaneously scripted as "unexceptional" state space (e.g. Steinberg, Tasch and Gerhardt, 2015); the most "un-traditional" territory has become "statised" in the most traditional ways. It has become an example of the successful implementation of international law - borders drawn on the basis of the UN Convention of the Law of the Sea (UNCLOS), and multilateral negotiations and collaborations happening in the most peaceful of ways ${ }^{2}$ (e.g. Strandsbjerg, 2012; Byers and Baker, 2013). Around the circumpolar table sit Russia, the US, Canada, and the five Nordic states - building relations that reach far beyond latitudinal borders. As such, the Arctic states are intriguing also due to the lack of geopolitical conflict in spite of those ongoing elsewhere. In the Arctic, the re-scripting of identity the application of "known" identity discourses to this "unknown" space - has been productive in spatialising it as a certain space, normalising it as a certain field (Medby, 2014, 2015).

And indeed, ever since the Arctic truly entered both public and political consciousness roughly a decade ago there have been active performances of Arctic statehood by all eight states with claims to the title: Norway, Sweden, Denmark/Greenland, Finland, Iceland, Russia, Canada, and the USA (see Keskitalo, 2004). Media has thrived on headlines of record low sea ice-covers, flag plantings, undiscovered petroleum promises, an 
Medby, I.A. (2018) 'Articulating state identity: 'Peopling' the Arctic state', Political Geography 62, pp. 116 -

125, DOI: $10.1016 /$ j.polgeo.2017.10.008.

Olympic torch relay, and starving polar bears, to mention but a few events that have brought the Arctic to southern audiences (e.g. Nyman, 2012; Wilson Rowe, 2013; Steinberg, Bruun and Medby, 2014; Woon, 2014). These are events that have also contributed to what is now a vibrant academic field of critical polar geopolitics (see Bruun and Medby, 2014; Powell and Dodds, 2014; Steinberg, Tasch and Gerhardt, 2015; Depledge, 2016; Keil and Knecht, 2017a). As ever more actors are voicing their simultaneous interest and concern, a paradoxical mix of future hopes and fears, the position of the region's eight states has been emphasised and re-emphasised through various statements and performances: as the privileged holders of knowledge and executors of power, the rightful stewards of Arctic space. Intertwined with the above practices of law and formal border-delimitations, the abstract effect, Arctic statehood, comes about and takes on meaning also through discourses of identity. That is to say, among the performative acts of Arctic statehood is a re-interpretation and re-articulation of identity - spatially and temporally positioning said state in relations of practice and power.

\section{$\underline{\text { Arctic identities }}$}

By wedding formal Arctic statehood to cultural Arctic nationhood, territory is wedded to population, and “an almost transcendental entity, the nation-state" is manufactured (Mitchell, 2006, p. 180) - the Arctic "nation-state" - "appearing as a structure containing and giving order and meaning to people's lives" (ibid.). As noted above, this ideological construct is politically powerful, and aids in generating support for what may otherwise be considered controversial. And importantly, also "giving order and meaning" to the lives of state officials: representing not just Arctic territory but Arctic people too fundamentally alters the approach to a given political question (Medby, 2015). Although large parts of the Arctic region are uninhabited 
Medby, I.A. (2018) 'Articulating state identity: 'Peopling' the Arctic state', Political Geography 62, pp. 116 -

125, DOI: $10.1016 /$ j.polgeo.2017.10.008.

oceanic spaces, the imaginary scripting of it as inherently part of the "homeland" opens up and closes down possible practices. Moreover, as noted, it works to position said state - at least in the eyes and minds of its practitioners - within relations of political power both with other states and with other spaces, institutions, and people. In other words, these identity discourses naturalise a certain, seemingly stable order (Knecht and Keil, 2013). This order, in turn, implies and conditions conduct. For example, an Arctic state is expected not just to hold rights, but also important responsibilities to act when relevant issues arise. What kind of action is deemed the "correct" one is limited by, inter alia, perceptions of "who" and "what" said state inherently is and should be.

The active re-interpretation of identity, connecting the Arctic to the national, is more pronounced in some of the Arctic states than others. The paper's three cases - Norway, Iceland, and Canada - have stood out in this regard. This may be linked to the priority given it in domestic policy, and perhaps to the privileged position “Arctic statehood" may grant states otherwise frequently described as "small” or "medium" powers (see e.g. Bátora, 2005; Arnold, 2010; Berdahl and Raney, 2010; Wilson Rowe, 2014; de Carvalho and Neumann, 2015; Lahn and Wilson Rowe, 2015). There, political rhetoric and performances have reiterated Arctic "nationhood" and identities parallel with the formal Arctic statehood, conferred by the latitudinally based membership in the Arctic Council ${ }^{3}$. For these states, the Arctic region has become important not only for environmental, economic, political, and symbolic reasons, but also - by virtue of their territories there the states in question take on a whole new international role; global peripherality has suddenly become centrality (see Shields, 1991). 
Medby, I.A. (2018) 'Articulating state identity: 'Peopling' the Arctic state', Political Geography 62, pp. 116 -

125, DOI: $10.1016 /$ j.polgeo.2017.10.008.

The "new" role then, "new" state identity perhaps, nevertheless cites discourses past and present. Hence, while they all emphasise their Arctic identities, the character thereof differs in practice, connecting to preexisting notions of Norwegian, Canadian, and Icelandic identities. It is beyond the scope of the present paper to give justice to the multifaceted and heterogenous ways in which national identities have been articulated, contested, and understood in each of the three states. However, of particular relevance here is their difference on Arctic geography: Although the Arctic Circle provides the official definition and criterion for Council membership, there are a number of other context-specific definitions also in use. Hence, when talking about "their" Arctic areas to domestic audiences, Norwegian politicians have tended to refer to "nordområdene" (literally, "the northern areas", but often translated as "the High North"), Canadian to "the North" (which often refers to the three northern Territories, or "north of $60^{\text {th }}$ [degree north]"), and Icelandic "norðurslóðir" (akin to the Norwegian). Interestingly, Iceland is actually entirely south of the Arctic Circle, except for a small uninhabited island off its northern coast, Grímsey ${ }^{1}$. However, by emphasising social definitions of the Arctic (e.g. as laid out in the Arctic Human Development Report 2004; 2015), Icelandic officials have posited that it is, in fact, the only country wholly within the Arctic (see Dodds and Ingimundarson, 2012). Also worth noting is that Norway is home to the indigenous Saami people, Canada to First Nations, Inuit, and Métis, while Iceland has no indigenous population; all of which are relations with significant implications for not only Arctic policy and politics, but also the ways in which identities are articulated. Hence, in sum their different histories, geographies, political contexts, and demographics offer three cases of state identity discourses that may share the basic elements, but include idiosyncratic interpretations of the meaning thereof (see e.g. Grant, 2001; Ingimundarson, 2010; Williams, 2010, 2011; Bergmann, 2011; Jensen and Hønneland, 2011; Baldwin, Cameron and Kobayashi, 2012; Jensen, 2013, 
Medby, I.A. (2018) 'Articulating state identity: 'Peopling' the Arctic state', Political Geography 62, pp. 116 -

125, DOI: $10.1016 /$ j.polgeo.2017.10.008.

2014, 2017; Halink, 2014; Loftsdóttir, 2014; Exner-Pirot, 2016). To understand how state identities may play out in practice, beyond the underlying conceptual framework, there is a need to acknowledge the inherent multivalence in adoption across time, space, and people.

In what follows, the above framework is discussed through the articulations of 49 state officials from Norway, Iceland, and Canada, all reflecting on their sense of Arctic identity. The respondents included 16 Norwegian, 12 Icelandic, and 21 Canadian state officials, representing 20 different ministries/departments, the Norwegian and Icelandic parliaments (Stortinget and Alpingi), and the Canadian Senate. Moreover, they represented a wide range of positions, from advisors to ministers, and included both indigenous and nonindigenous people ${ }^{4}$. The aim was to include the widest range possible of agencies, institutions, ranks, and positions, in order to gain a broad view of how Arctic state identities are articulated by personnel. As such, the only criteria for participation was employment at the state/federal level, irrespective of particular policy responsibilities. While they all spoke as personnel of Arctic states, they nevertheless did so in a personal capacity, reflecting views and sharing stories that were theirs under the strict promise of confidentiality. Respecting this, specific ranks or institutions are also not the point here; although there is no doubt that there are differences between these both in terms of identification and influence, what is here of more relevance is the shared sense of identity exceeding professional position. And indeed, allowing officials to reflect and narrate the story they wished to tell, the aim is to open up a space for the people of the state and their subjective articulations of meaning, of their sense of identity as such. Articulations, however, are never a solo act, but the result of co-actors' inter-action and the relations between them. In the end, and as will 
Medby, I.A. (2018) 'Articulating state identity: 'Peopling' the Arctic state', Political Geography 62, pp. 116 -

125, DOI: $10.1016 /$ j.polgeo.2017.10.008.

become clear, it is the entanglement, overlap, and overspill of innumerable subject-positions and relations that together speak the Arctic state into being.

\section{Articulations of Arctic State Identity}

Articulations of own sense of Arctic identity, which in effect cite and perform discourses, are here presented within the conceptual framework offered above. First discussing spatiotemporal boundaries of discourse, as the limits of what may be meaningfully said, done, thought, and enacted as Arctic states. And secondly, while a title as an Arctic state, and indeed identity as such, come about through geographies and histories, these performances - or "articulations" - play out neither to nor from, but between subjects; they are always, inherently relational. As such, Arctic spaces and times, natures and (hi)stories, take on meaning in social interaction. The context of a statement of identity matters as much for representation as reception. An Arctic state identity is therefore never static nor an object to be "held", but a relation that forever flows iteratively interpreted and re-interpreted. Encounters and interactions are of course never neatly scaled, but Arctic state identities are here heuristically presented as they were often explained by respondents: as an effect of relations that are international, national, sub-national, and personal - and, indeed, often several all at once. 
Medby, I.A. (2018) 'Articulating state identity: 'Peopling' the Arctic state', Political Geography 62, pp. 116 -

125, DOI: $10.1016 /$ j.polgeo.2017.10.008.

\section{Spatiotemporal boundaries}

Firstly, Arctic spatialities refer not only to a (home)land in which identity may be "rooted", but as more than this: Arctic space as place with heterogeneous connections between the human and nonhuman: of environments, natural forces, climates, weathers, floras, and faunas (see Massey, 2005; Clark, 2011; Squire, 2016). Noted by several of the interviewees across the three states, Arctic nature and natural forces are what supposedly unites the group of eight despite their differences; as one Icelandic official explained: "When you have a common - even if it's only a common physical feature like the Aurora Borealis and the long dark winters and these glaciers and snow - then that of course helps to have this circumpolar identity". Another spoke of a "special energy" shared only among those from the circumpolar countries, and continued, with a smile: "it's just the atmosphere, the people, the mentality. Cool on the outside and very wild on the inside sometimes!”. Arctic statehood is here understood as more than latitudinal: it is natural and environmental - spatialities that in turn supposedly unite and define people. In this manner, discursive boundaries are themselves produced in interaction, and collective identity in the sharing of subjective corporealities - or the shared lack thereof, as was often the case among Canadian officials with no first-hand experience of the North. In the words of one: "I think the identity of Canada as a Northern nation - as a very cold, and our winter climate - is a huge, a very, very strong national identity. [...] Canadians know winter.”

And interestingly, as a geographical region that is largely oceanic, the spatialities of "being" Arctic was despite largely agreed upon lines and latitudes - expressed differently from person to person, as well as from state to state. Without reducing subjects' individual views, there were identifiable contrasts between 
Medby, I.A. (2018) 'Articulating state identity: 'Peopling' the Arctic state', Political Geography 62, pp. 116 -

125, DOI: $10.1016 /$ j.polgeo.2017.10.008.

the three states in this regard: the Arctic was in the hydrocarbon-wealthy state Norway often spoken of in terms of oceanic and sub-oceanic resources, the sea-bed almost like arable land: "[O]ur geography - it is our identity. That is, we are a country far, far north with large ocean areas; limited land area, but still. In an Arctic context, that defines our cooperation patterns, how we act, and more" (see Eriksen and Neumann, 2011; Kristoffersen, 2015). For Icelandic officials, Arctic spatiality was often articulated as oceanic currents, flows, and mobile connections between the island state and the world: "[B]ecause the ocean's currents go back and forth and we are dependent on that. That's one of the main [reasons] behind the identity of Iceland in the Arctic" (see Einarsson, 1996; Hastrup, 2008; Bergmann, 2011). And in Canada, the Arctic was frequently described as a solid and frozen frontier, land-like if not land, and often mythical, fragile, intangible "[I]t gives me, as a Canadian, a sense that in this country there's a lot of space still; there's a lot of wildness, which I identify with as a Canadian. And that wildness is in the Arctic" (see Grant, 2001; Bennett et al., 2016). Different imaginaries clearly suggest different political approaches; and yet, in all three cases, they function to guide the conduct of Arctic statehood in one direction or another.

Secondly, Arctic political practice is regulated by (or along) the seemingly linear path of history - of time progressing from the state's Arctic past towards its Arctic future. As one Icelandic politician reflected on the population's sense of Arctic identity - or lack thereof: “I don't think that we have, maybe, that we are very aware of, every day, in our daily lives, that we are an Arctic nation. We just are and always have been”. Having been marginal to national narratives until very recently, a process of re-interpretation, of re-focusing the lens of history towards the Arctic, is at present taking place in all three states, albeit in different ways. 
Medby, I.A. (2018) 'Articulating state identity: 'Peopling' the Arctic state', Political Geography 62, pp. 116 -

125, DOI: $10.1016 /$ j.polgeo.2017.10.008.

The Norwegian Minister of Foreign Affairs Børge Brende (2015) offered the following claim of Arctic identity in a speech:

As a nation of seafarers and fishermen, Norwegians have always lived off the sea. Polar exploration is an integral part of our national identity. $80 \%$ of maritime traffic in the Arctic passes through Norwegian waters. Almost 90\% of our export revenues come from resources and economic activity and in our sea areas. Our long coastline, traditions and innovation go hand in hand.

Suddenly in sharp relief, the memories of the past and imaginations of the future that connect people to the space from which the title of Arctic statehood is drawn are, however, always articulated in the present. Not just an instrumentalist construction of a "path", these narratives come about through the telling and re-telling of shared stories (Cameron, 2009, 2015); they guide the orator as much as the listener, the elected as much as the electorate. In fact, in the act of its pronunciation, it is not merely an Arctic narrative that is produced, but it simultaneously produces its pronouncer: subjectivity gained as Arctic state representative. Again, these boundaries were unique to each state (indeed, each official) - the Arctic story embedded in the national, familiar stories interwoven with the polar. Norwegian seafarers and polar explorers; Icelandic Vikings and fishermen; Canadian settlers and discoverers (and occasionally, Inuit) are all scripted into the politics of the present. As Edward Said (2000, p. 176) reminds us, history is "far from" [...] a neutral exercise in facts and basic truths", but rather "a nationalist effort" in order to "construct a desireable loyalty" (ibid., see also Gellner, 1983; Hobsbawm and Ranger, 1983). Importantly, however, it is also true that those who grow up to become state personnel are subject to the same histories of "Arcticness". Embedded in school curricula and museum exhibitions, and represented equally in spectacular and mundane ways (see 
Medby, I.A. (2018) 'Articulating state identity: 'Peopling' the Arctic state', Political Geography 62, pp. 116 -

125, DOI: $10.1016 /$ j.polgeo.2017.10.008.

Benwell, 2014), the domestication of the Arctic renders also the domestic Arctic (see Crang and Tolia-

Kelly, 2010). A Canadian offered the following reflection:

Our history books, and particularly the history that I grew up being taught, focuses a lot on the importance of the North [...] So, I think kids in Canada grow up with a lot of stories about the North. [...] a sense of how important the North is to Canada.

In this manner, "being" Arctic is discursively normalised and nationalised, an Arctic present that has followed from an Arctic past. Moreover, this present is always one of seeming progression - and indeed, this may be one way in which performances of state identity contrasts with that of national such, namely its temporal privileging of the future. In particular in the case of Iceland, state personnel - such as this Icelandic parliamentarian - saw Arctic awareness, engagement, and identity as something in-the-making, yet-tocome:

[W]e have to be prepared, and have a plan before this happens, and know exactly where we stand - legally. And like I said, have good cooperation, good political connections; just, you know, to be part of it, the making of the future of the Arctic. (emphasis added).

That is, present political practice, the enactment of the Arctic state, is always anticipatory and preparatory (see Dodds, 2013); challenges and opportunities for the state to face sooner rather than later, and indeed, a particular outlook that is the responsibility of the state representative; in the words of a Norwegian official:

As a politician, and often in central positions in the state administration, you know that you have a position that is bigger than yourself; and that requires you to lift your gaze and not just be self-centred in the decisions and judgments you make.

In short, a state identity entails not just a sense of rootedness, but a seeming responsibility to consider how the branches will grow further into the Arctic future. 
Medby, I.A. (2018) 'Articulating state identity: 'Peopling' the Arctic state', Political Geography 62, pp. 116 -

125, DOI: $10.1016 /$ j.polgeo.2017.10.008.

\section{Relationality through and beyond scales}

Arctic geographies and histories may be what defines the Arctic state; yet the way it comes into being is always a matter of relational articulations. Internationally, an Arctic state identity is one of membership and exclusivity: an Arctic state among states in a circumpolar region and a globalising world. For these "small" to "medium power"-states, participation in e.g. the Arctic Council, and their privileged position therein is an opportunity to engage and influence internationally; in the words of one Icelandic respondent, this membership "gives us a role in the society of other countries". It is an identity with which both rights and responsibilities follow - both of which require certain political performativity on the stage of the international. For Norwegian personnel, it was frequently considered an international asset: "placing us in a position where you are perceived as important, and the decisions we then make in this policy area will also be important for how other countries see us". For Icelandic personnel, it was described as an opportunity for simultaneously enacting involvement and independence, Arctic membership "gives us a role in the society of other countries". And for Canadian personnel, it served as a prompt for stewardship and even defence; in the words of one:

While I said that Canada has always had a strong sort of Northern and Arctic identity, I would have to say though that we are going through a significant pivot point, where we are recognising that the entire world now is very interested in the Arctic as well.

For all three, "being" an Arctic state is a role to be ceaselessly enacted on the global stage. In the words one an official in the Norwegian Ministry of Foreign Affairs, the government "highly deliberately" uses its High North-focus as a way of demonstrating internationally that "we are not the largest nation in the Arctic, but at 
Medby, I.A. (2018) 'Articulating state identity: 'Peopling' the Arctic state', Political Geography 62, pp. 116 -

125, DOI: $10.1016 /$ j.polgeo.2017.10.008.

least we are a leading nation in the Arctic" (see de Carvalho and Neumann, 2015; Lahn and Wilson Rowe, 2015). In other words, political practices - including investments, exercises, and support for various Arctic initiatives - are all part of the active, ongoing production of not only legitimacy (see Jeffrey, McConnell and Wilson, 2015) but a certain role and identity on the international stage - among both other Arctic and nonArctic states and stakeholders. The above Norwegian official continued that Arctic strategies are not enough on paper, but need to be followed up with concrete action:

Building an [Arctic] identity, you build a brand - that is, Norway: a brand - which requires that the state - the state administration, government and Parliament - have to deliver something within it. So it drives development.

Looking to the national community, Arctic state identity connects to notions of national identity. For example, Arctic practices are also Icelandic practices; the two cannot easily be disentangled, as highlighted by the previous assertion that "We just are and always have been". In all three states, symbols such as the polar bear and northern lights can now be found ubiquitously across southern towns and capitals: it has become part of the boringly familiar, no longer exotic but simply normal, a part of "who we are" (see Billig, 1995; Benwell, 2014; Paasi, 2015). In the words of a senior Canadian state official: "Canada has a strong sense of identity with the polar bear. [...] there are different things that are, you know, things that are North, and Canada - it's just part of our national identity". As the Arctic title becomes ever more used, ever more normalised, society-including people in governmental offices - in effect become Arctic too, reminded through the everyday, familiar, and banal, and importantly, unquestioned. 
Medby, I.A. (2018) 'Articulating state identity: 'Peopling' the Arctic state', Political Geography 62, pp. 116 -

125, DOI: 10.1016/j.polgeo.2017.10.008.

Despite the polar bear's ability to remind people of their shared state, internal heterogeneity also means that an Arctic state identity differs within. Distances and (dis)connections between north and south provide divergent attachments to the region - perhaps more so in Canada than Norway, and even less so in Iceland. Indeed, some Icelandic officials described their sense of Arctic identity in interviews with the caveat that it was "different" than Norway and Canada, partly due to indigeneity and to histories of exploration. Either way, this distanced otherness - or Margaret Atwood's (2004) "strangeness" - may breed both romanticism and alienation, attraction and detachment. As noted also above, one Canadian interviewee described it as the following:

[I]n our national identity, our imagination includes the North. We see it on the maps, our national broadcaster; there's lots of documentaries and news-stories about life in the North, and what's happening there... But... so at the level of our mental imagination I think it has a place, but generally speaking, it's pretty far away and it's not part of our day-to-day.

And, with its latitudinal definition, domestic "Arcticness" becomes hierarchical based on relative northernness - there is always somewhere more Arctic (Medby, 2014). Arctic state identities thus take on a different meaning when articulated in relation to a fellow national but northern other.

Moreover, indigeneity plays into claims of identity: Saami and Inuit in Norway and Canada respectively were often described as that: more Arctic. Referred to by a Norwegian official as the "local democracy in the Arctic", the Saami were recognised by him as those who would be "left with the positive - that is, part of the positive things, hopefully, if we do this well - but also the negative consequences if we do this badly". And yet, the central, majority "we" remains in opposition to the peripheral, minority "they"; the former with 
Medby, I.A. (2018) 'Articulating state identity: 'Peopling' the Arctic state', Political Geography 62, pp. 116 -

125, DOI: $10.1016 /$ j.polgeo.2017.10.008.

agency to act, the latter primarily to react. Interestingly, however, these intra- or sub-state differences may also be seen in light of a normative diversity (see Matejskova and Antonsich, 2015). And, as such, their inclusion provides not a threat but an advantage to the state. Indeed, seemingly oblivious to the deeply negative association many would have to the Cold War-era history of forced displacement of Inuit families to inhospitable High Arctic lands as "flagposts" (Marcus, 1995; see also Shadian, 2012), one senior Canadian interviewee mused:

We started realising - what does the sovereignty in the Arctic mean for Canada? Is it a military presence there, or is the resource extraction, or is just having people live there? And it's beginning to look like it's having people live there.

Political practices and performances of partnering, of respect, and even of apologies for historical wrongs thereby, paradoxically, strengthen the state-level claim to Arctic identity too (see Arnold, 2012).

Although a collective and social identity, Arctic state identity is also understood as part of the "self", part of the subject's personal story. A surprising number of interviewees brought up stories of childhoods and families, such as: "Because I am born, have family, and have spent a lot of time in Northern Norway, I have a completely different identity and emotional attachment to Northern Norway and to the Arctic [...]”. Arctic state personnel may perform the state, but will always do so through the modes and manners developed through subjective relations that far exceed their four office walls - as highlighted also by the Icelander's opening quote. As such, Arctic spatiality was talked about as embodied experiences, of feeling cold, of knowing winter. While several Canadian officials noted their personal experience and interest in e.g. icehockey, skating, and skiing as influential in their personal sense of connection to the Arctic region, the 
Medby, I.A. (2018) 'Articulating state identity: 'Peopling' the Arctic state', Political Geography 62, pp. 116-

125, DOI: $10.1016 /$ j.polgeo.2017.10.008.

elemental held additional significance for an indigenous official: "we still have a lot of people alive today who were born on the ice, belonging, who belong to this area”. Here, belonging and attachment - even understanding the region for the development of international policy - was tied to the intimately personal, familial, even birth.

Not just spatialities, but Arctic temporalities too was articulated through familiar and personal (hi)stories, childhood and memory. Professional positions as state officials were part of - leading to and from something much more: of love and friendship, emotion and embodiment. A Canadian state representative offered the following, gazing out the window, far beyond audio-recorders and interviewer:

[W]hen I started thinking about it, I do have an identity with the Arctic for a number of reasons... why? My father spent thirty years in the Arctic as a naval officer during the Cold War. [...] So I grew up with these stores about the Arctic. So I knew my dad as an Arctic person; and in some ways, I'm trying to maybe follow in his footsteps a little bit, you know. [...] To keep his work alive a little bit, and learn about the Arctic the way he saw it.

In this manner, the Arctic state bears traces of - indeed, is constituted by - its innumerable enacting actors. Regulated in time and space, mediated through all scales of interaction; in the end, an Arctic state is a "peopled" one, and state identity is about relating to others.

\section{Conclusion}

The way in which Arctic statehood comes into being is, in the end, an effect of numerous performances invoking it through words and practice. What is really at stake in the articulation of Arctic state identities 
Medby, I.A. (2018) 'Articulating state identity: 'Peopling' the Arctic state', Political Geography 62, pp. 116 -

125, DOI: $10.1016 /$ j.polgeo.2017.10.008.

then is the reification of an idea, of what it means to "be" and "represent" an Arctic state, and how this in turn may condition what it possibly can be. However, these articulations are as heterogenous as their articulators, demonstrating how Arctic political practices bear traces of its many practitioners. Even though the reflections offered by the participants are by no means exhaustive, they allow a glimpse of what it might mean to grant the Arctic state, or rather its personnel, humanity, and indeed, to see them as part of a society too. Indeed, all states are effects of practices that are invariably performed by people, who all relate to, identify with, connect with their professional role also through personal experiences, emotions, and imaginaries. Or rephrased, the state is inherently "peopled"; it is a product of the social and relational, imbued with all that comes therewith.

Through the conceptual framework of "state identity" discourses, the aim here has been to contribute an understanding that recognises how their articulation may be regulated within geographical and historical boundaries; yet, the ways in which the state comes about as such, "materialises" in the world, are mediated through social and political relations across all scales of interaction. In this manner, the state emerges neither as only individualised nor wholly institutional; rather, the many stories by the people of the state highlight how the subjective and the collective intertwine and co-constitute each other. The state too is produced through embodied experiences and material encounters; and vice versa, corporeal senses become codified through vast geographical imaginaries. To scholarship that seeks to "people" political geography, the article has thereby contributed an approach to consider "state identities", highlighting the weaving together of spatiotemporalities and relationalities, the professional and the personal also at the level of the state. 
Medby, I.A. (2018) 'Articulating state identity: 'Peopling' the Arctic state', Political Geography 62, pp. 116 -

125, DOI: $10.1016 /$ j.polgeo.2017.10.008.

What is also clear from the above discussion is that there remains much yet to be studied on the topic of state identity - many more stories to be told, heard, and relations to be built. In particular three avenues for further research are here suggested: firstly, exploring the ways in which discourses of state identity become not just articulated but embodied and performed in interaction, including how the above articulations may translate to concrete policy. Secondly, how state identity articulations and enactments are received, interpreted; or, indeed, resisted, challenged, and contested beyond those employed by said state. And thirdly, how individual characteristics may influence both identification and decision-making agency, e.g. exploring the role of specific ranks or positions, gender, age, education, and so on. On all of these topics, political geographers will have much to contribute both to the Arctic and to questions of statehood writ large.

In the end, politics is about people and the relations between them. The implications of a concept of "state identity" therefore extend beyond the contribution of another analytical matrix. Recognising the state as "peopled" - and recognising the significance of these people's sense of identities - requires a thorough assessment of the ways in which the state is approached methodologically and conceptually, with practical, ideological, and ethical implications. And with this, "society" is not constructed in opposition to a faceless "state", not in a position of perpetual asymmetrical power, but may instead be granted a discursive position of relationality - where there is possibility for said interaction, for change, for political dialogue. As such, acknowledging the identities of state personnel is one step towards breaking down ingrained dichotomies, and start recognising co-constitution and co-production of not only Arctic but social affairs writ large. The conclusion is therefore a hopeful one, and an impassioned call for more political engagement, more 
Medby, I.A. (2018) 'Articulating state identity: 'Peopling' the Arctic state', Political Geography 62, pp. 116 -

125, DOI: $10.1016 /$ j.polgeo.2017.10.008.

interaction, discussion, and contestation - not to, not against, but with the people of the state too. It is through active relating that power relations may be changed.

\section{References}

Abrams, P. (1988) 'Notes on the Difficulty of Studying the State [1977]', Journal of Historical Sociology, 1(1), pp. 58-89.

Agnew, J. (1999) 'Mapping Political Power Beyond State Boundaries: Territory, Identity, and Movement in World Politics', Millennium - Journal of International Studies, 28(3), pp. 499-521. doi:

$10.1177 / 03058298990280030701$.

Ahlenius, H. (2016) 'Arctic map, political'. UNEP-GRID Arendal (Reference Maps). Available at: https://www.grida.no/resources/7845 (Accessed: 31 August 2017).

Ahmed, S. (2004) 'Collective Feelings: Or, the Impressions Left by Others', Theory, Culture \& Society, 21(2), pp. 25-42. doi: 10.1177/0263276404042133.

Anderson, B. (1983) Imagined Communities: Reflections on the origin and spread of nationalism. London: Verso.

Anderson, B. (2009) 'Affective Atmospheres', Emotion, Space and Society, 2(2), pp. 77-81. doi:

10.1016/j.emospa.2009.08.005.

Antonsich, M. (2009) 'On Territory, the Nation-State and the Crisis of the Hyphen', Progress in Human Geography, 33(6), pp. 789-806. doi: 10.1177/0309132508104996.

Antonsich, M. (2011) 'Rethinking territory', Progress in Human Geography, 35(3), pp. 422-425. doi: $10.1177 / 0309132510385619$.

Arnold, S. (2010) 'Home and Away: Public Diplomacy and the Canadian Self', in Beier, J. M. and Wylie, L. (eds) Canadian foreign policy in critical perspective. Toronto: Oxford University Press, pp. 15-28.

Arnold, S. (2012) 'Constructing an Indigenous Nordicity: The "New Partnership" and Canada's Northern Agenda: Constructing an Indigenous Nordicity', International Studies Perspectives, 13(1), pp. 105-120. doi: 10.1111/j.1528-3585.2011.00455.x. 
Medby, I.A. (2018) 'Articulating state identity: 'Peopling' the Arctic state', Political Geography 62, pp. 116 -

125, DOI: 10.1016/j.polgeo.2017.10.008.

Atwood, M. (2004) Strange Things: The Malevolent North in Canadian Literature. London: Virago.

Baldwin, A., Cameron, L. and Kobayashi, A. (eds) (2012) Rethinking the Great White North: Race, nature, and the historical geographies of whiteness in Canada. Vancouver: UBC Press.

Bátora, J. (2005) 'Public Diplomacy in Small and Medium-Sized States: Norway and Canada', Netherlands Institute of International Relations 'Clingendael'. Edited by D. Kelly and J. Melissen. (Discussion Papers in Diplomacy), pp. 1-26.

Bennett, M. M. et al. (2016) 'Articulating the Arctic: contrasting state and Inuit maps of the Canadian north’, Polar Record, pp. 1-15. doi: 10.1017/S0032247416000164.

Benwell, M. C. (2014) 'From the Banal to the Blatant: Expressions of nationalism in secondary schools in Argentina and the Falkland Islands', Geoforum, 52, pp. 51-60. doi: 10.1016/j.geoforum.2013.12.006.

Benwell, M. C. and Dodds, K. (2011) 'Argentine Territorial Nationalism Revisited: The Malvinas/Falklands dispute and geographies of everyday nationalism’, Political Geography, 30(8), pp. 441449. doi: 10.1016/j.polgeo.2011.09.006.

Berdahl, L. and Raney, T. (2010) 'Being Canadian in the world: Mapping the contours of national identity and public opinion on international issues in Canada', International Journal, 65(4), pp. 995-1010.

Bergmann, E. (2011) 'On the Edge: Iceland's national discourse and the European project', in Toriz Ramos, C. (ed.) Ideas of Europe in national political discourse. Bologna: Il mulino, pp. 293-323. Available at:

http://skemman.is/en/stream/get/1946/13518/32393/1/Bergmann_2011_SENT_\$00282\$0029.pdf.

Billig, M. (1995) Banal Nationalism. London: SAGE.

Bondi, L. (1993) 'Locating Identity Politics', in Keith, M. and Pile, S. (eds) Place and the Politics of Identity. London: Routledge, pp. 84-101.

Bratsis, P. (2007) Everyday Life and the State. Boulder: Routledge.

Brende, B. (2015) 'Opening Speech: Arctic Frontiers Conference 2015 (19 January)'. Arctic Frontiers Conference, UiT - The Arctic University of Norway, Tromsø, Norway, 19 January. Available at:

https://www.regjeringen.no/no/aktuelt/arctic_innlegg/id2362601/ (Accessed: 21 March 2016).

Brenner, N. (2004) New State Spaces: Urban Governance and the Rescaling of Statehood. New York: Oxford University Press, US.

Bruun, J. M. and Medby, I. A. (2014) 'Theorising the Thaw: Geopolitics in a Changing Arctic', Geography Compass, 8(12), pp. 915-929. doi: 10.1111/gec3.12189.

Butler, J. (1999) Gender Trouble: Feminism and the subversion of identity. London: Routledge. 
Medby, I.A. (2018) 'Articulating state identity: 'Peopling' the Arctic state', Political Geography 62, pp. 116 -

125, DOI: $10.1016 /$ j.polgeo.2017.10.008.

Butler, J. (2011) Bodies That Matter. 2nd edn. London: Routledge.

Byers, M. and Baker, J. (2013) International Law and the Arctic. Cambridge University Press.

Cameron, E. (2009) 'Summer Stories: (Re)Ordering the Canadian Arctic', Antipode, 41(1), pp. 216-219. doi: $10.1111 /$ j.1467-8330.2008.00667.x.

Cameron, E. (2015) Far Off Metal River: Inuit lands, settler stories, and the makings of the contemporary Arctic. Vancouver ; Toronto: UBC Press.

de Carvalho, B. and Neumann, I. B. (eds) (2015) Small State Status Seeking: Norway's Quest for International Standing. Oxon: Routledge.

Chatterjee, P. (2004) The Politics of the Governed: Reflections on Popular Politics in Most of the World. Columbia University Press.

Clark, N. (2011) Inhuman Nature: Sociable life on a dynamic planet. Los Angeles, CA: SAGE (Theory, culture \& society).

Closs Stephens, A. (2013) The persistence of nationalism: from imagined communities to urban encounters. London ; New York: Routledge (Interventions).

Closs Stephens, A. (2015) 'The Affective Atmospheres of Nationalism', cultural geographies, 23(2), pp. 181198. doi: $10.1177 / 1474474015569994$.

Connolly, W. E. (1991) Identity/Difference: Democratic negotiations of political paradox. Ithaca, N.Y.: Cornell University Press.

Corbridge, S. (2005) Seeing the State: Governance and Governmentality in India. Cambridge ; New York: Cambridge University Press.

Crang, M. and Tolia-Kelly, D. P. (2010) 'Nation, Race, and Affect: Senses and Sensibilities at National Heritage Sites’, Environment and Planning A, 42(10), pp. 2315-2331. doi: 10.1068/a4346.

Depledge, D. (2016) 'Climate Change, Geopolitics, and Arctic Futures', in Sosa-Nunez, G. and Atkins, E. (eds) Environment, Climate Change and International Relations. Bristol: E-International Relations Publishing, pp. $162-174$.

Dixon, D. P. and Marston, S. A. (2011) 'Introduction: feminist engagements with geopolitics', Gender, Place \&Culture, 18(4), pp. 445-453. doi: 10.1080/0966369X.2011.583401.

Dodds, K. (2013) 'Anticipating the Arctic and the Arctic Council: Pre-emption, precaution and preparedness', Polar Record, 49(02), pp. 193-203. doi: 10.1017/S0032247412000198. 
Medby, I.A. (2018) 'Articulating state identity: 'Peopling' the Arctic state', Political Geography 62, pp. 116 -

125, DOI: $10.1016 /$ j.polgeo.2017.10.008.

Dodds, K. and Ingimundarson, V. (2012) 'Territorial Nationalism and Arctic Geopolitics: Iceland as an Arctic coastal state', The Polar Journal, 2(1), pp. 21-37. doi: 10.1080/2154896X.2012.679557.

Dowler, L. and Sharp, J. (2001) 'A Feminist Geopolitics?', Space and Polity, 5(3), pp. 165-176. doi: $10.1080 / 13562570120104382$.

Edensor, T. (2002) National Identity, Popular Culture and Everyday Life. Oxford: Berg Publishers.

Einarsson, N. (1996) 'A Sea of Images: Fishers, Whalers, and Environmentalists', in Pálsson, G. and Durrenberger, E. P. (eds) Images of Contemporary Iceland: Everyday Lives and Global Contexts. Iowa City: University of Iowa Press, pp. 46-59.

Einarsson, N. et al. (eds) (2004) Arctic Human Development Report. Copenhagen: Nordic Council of Ministers.

Eriksen, T. H. and Neumann, I. B. (2011) 'Fra slektsgård til oljeplattform: - Norsk identitet og Europa', Internasjonal Politikk, 69(3), pp. 413-436.

Exner-Pirot, H. (2016) 'Canada's Arctic Council chairmanship (2013-2015): a post-mortem', Canadian Foreign Policy Journal, 22(1), pp. 84-96. doi: 10.1080/11926422.2015.1115772.

Fearon, J. D. (1999) 'What is Identity (As We Now Use the Word)?' Department of Political Science, Stanford University.

Foucault, M. (1972) Archaeology of Knowledge [1969]. London: Tavistock.

Foucault, M. (2002) The Order of Things: An Archaeology of the Human Sciences [1966]. Psychology Press.

Fukuyama, F. (1992) The End of History and the Last Man. New York: Free Press.

Gellner, E. (1983) Nations and Nationalism. Oxford: Blackwell.

Graczyk, P. et al. (2017) 'Preparing for the Global Rush: The Arctic Council, Institutional Norms, and the Socialisation of Observer Behaviour', in Keil, K. and Knecht, S. (eds) Governing Arctic Change: Global Perspectives. London: Palgrave Macmillan, pp. 121-140.

Graczyk, P. and Koivurova, T. (2014) 'A new era in the Arctic Council's external relations? Broader consequences of the Nuuk observer rules for Arctic governance', Polar Record, 50(3), pp. 225-236. doi: $10.1017 /$ S0032247412000824.

Grant, S. D. (2001) Canada and the Idea of North. Montréal: McGill-Queen’s University Press.

Halink, S. (2014) 'The Icelandic Mythscape: Sagas, Landscapes, and National Identity', National Identities, 16(3). 
Medby, I.A. (2018) 'Articulating state identity: 'Peopling' the Arctic state', Political Geography 62, pp. 116 -

125, DOI: $10.1016 /$ j.polgeo.2017.10.008.

Harrison, P. (2000) 'Making Sense: Embodiment and the Sensibilities of the Everyday', Environment and Planning D: Society and Space, 18(4), pp. 497-517. doi: 10.1068/d195t.

Hastrup, K. (2008) 'Icelandic Topography and the Sense of Identity', in Jones, M. and Olwig, K. (eds) Nordic Landscapes: Region and Belonging on the Northern Edge of Europe. Minnesota: University of Minnesota Press, pp. 53-76.

Hobsbawm, E. J. and Ranger, T. O. (eds) (1983) The Invention of Tradition. Cambridge: Cambridge University Press (Past and present publications).

Hyndman, J. (2004) 'Mind the Gap: Bridging Feminist and Political Geography through Geopolitics', Political Geography. (Reconceptualizing the State), 23(3), pp. 307-322. doi: 10.1016/j.polgeo.2003.12.014. Ingimundarson, V. (2010) “'A Crisis of Affluence”: the Politics of an Economic Breakdown in Iceland', Irish Studies in International Affairs, 21(1), pp. 57-69. doi: 10.3318/ISIA.2010.21.57.

Jameson, F. (1991) Postmodernism, or, the cultural logic of late capitalism. London: Verso.

Jeffrey, A., McConnell, F. and Wilson, A. (2015) 'Understanding legitimacy: Perspectives from anomalous geopolitical spaces', Geoforum, 66, pp. 177-183. doi: 10.1016/j.geoforum.2015.09.005.

Jensen, L. C. (2013) Norway on a High in the North: A discourse analysis of policy framing. University of Tromsø. Available at: http://hdl.handle.net/10037/4737 (Accessed: 3 June 2014).

Jensen, L. C. (2014) 'The High North represents the potential, the optimism, the tensions and the bridge', Barents Studies. (Young researchers of the Barents Region), 1(1), pp. 128-131.

Jensen, L. C. (2017) 'An Arctic "marriage of inconvenience”: Norway and the othering of Russia', Polar Geography, 40(2), pp. 121-143. doi: 10.1080/1088937X.2017.1308975.

Jensen, L. C. and Hønneland, G. (2011) 'Framing the High North: Public Discourses in Norway after 2000’, Acta Borealia, 28(1), pp. 37-54. doi: 10.1080/08003831.2011.575659.

Jones, A. and Clark, J. (2015) 'Mundane diplomacies for the practice of European geopolitics', Geoforum, 62, pp. 1-12. doi: 10.1016/j.geoforum.2015.03.002.

Jones, R. (2007) People/States/Territories: The Political Geographies of British State Transformation. Oxford: Blackwell (RGS-IBG book series).

Jones, R. (2012) 'State encounters', Environment and Planning D: Society and Space, 30(5), pp. 805-821. doi: $10.1068 / \mathrm{d} 9110$.

Jones, R. and Merriman, P. (2009) 'Hot, Banal and Everyday Nationalism: Bilingual road signs in Wales', Political Geography, 28(3), pp. 164-173. doi: 10.1016/j.polgeo.2009.03.002. 
Medby, I.A. (2018) 'Articulating state identity: 'Peopling' the Arctic state', Political Geography 62, pp. 116 -

125, DOI: $10.1016 /$ j.polgeo.2017.10.008.

Keil, K. and Knecht, S. (eds) (2017a) Governing Arctic Change: Global Perspectives. London: Palgrave Macmillan.

Keil, K. and Knecht, S. (2017b) 'Introduction: The Arctic as a Globally Embedded Space', in Keil, K. and Knecht, S. (eds) Governing Arctic Change: Global Perspectives. London: Palgrave Macmillan, pp. 1-18.

Kendall, G. and Wickham, G. (1999) Using Foucault's Methods. London: SAGE Publications (Introducing qualitative methods).

Keskitalo, E. C. H. (2004) Negotiating the Arctic: The construction of an international region. London: Routledge.

Knecht, S. and Keil, K. (2013) 'Arctic Geopolitics Revisited: Spatialising governance in the circumpolar North', The Polar Journal, 3(1), pp. 178-203. doi: 10.1080/2154896X.2013.783276.

Kristoffersen, B. (2015) 'Opportunistic Adaptation: New discourses on oil, equity and environmental security', in O'Brien, K. and Selboe, E. (eds) The adaptive challenge of climate change. Cambridge: Cambridge University Press, pp. 140-159.

Kuus, M. (2008) 'Professionals of Geopolitics: Agency in International Politics', Geography Compass, 2(6), pp. 2062-2079. doi: 10.1111/j.1749-8198.2008.00172.x.

Kuus, M. (2014) Geopolitics and Expertise: Knowledge and authority in European diplomacy. Chichester, West Sussex, UK: John Wiley \& Sons, Inc.

Kuus, M. (2015) 'Symbolic Power in Diplomatic Practice: Matters of style in Brussels', Cooperation and Conflict, 50(3), pp. 368-384. doi: 10.1177/0010836715574914.

Kuus, M. (2016) “"To Understand the Place”: Geographical Knowledge and Diplomatic Practice', The Professional Geographer, 68(4), pp. 546-553. doi: 10.1080/00330124.2015.1099450.

Lahn, B. and Wilson Rowe, E. (2015) 'How to be a "front-runner": Norway and international climate politics', in de Carvalho, B. and Neumann, I. B. (eds) Small State Status Seeking: Norway’s Quest for International Standing. Oxon: Routledge, pp. 126-145.

Larsen, J. N. and Fondahl, G. (eds) (2015) Arctic Human Development Report: Regional Processes and Global Linkages. Copenhagen: Nordic Council of Ministers. Available at: http: / / urn.kb.se/resolve?urn=urn:nbn:se:norden:org:diva-3809 (Accessed: 27 February 2015).

Loftsdóttir, K. (2014) “We who live in the Arctic region”: Iceland's belonging in the Arctic', Arctic Encounters: Researchers' Blog, 27 February. Available at:

http: / / www.arcticencounters.net/post.php?s=2014-02-27-we-who-live-in-the-arctic-region-icelandsbelonging-in-the-arctic (Accessed: 3 May 2014). 
Medby, I.A. (2018) 'Articulating state identity: 'Peopling' the Arctic state', Political Geography 62, pp. 116 -

125, DOI: 10.1016/j.polgeo.2017.10.008.

Marcus, A. R. (1995) Relocating Eden: The Images and Politics of Inuit Exile in the Canadian Arctic. Hanover: University Press of New England (Arctic Visions). Available at:

http://www.dartmouth.edu/ library/digital/publishing/books/marcus1995/ (Accessed: 10 October 2015).

Massaro, V. A. and Williams, J. (2013) 'Feminist Geopolitics', Geography Compass, 7(8), pp. 567-577. doi: $10.1111 /$ gec 3.12054 .

Massey, D. B. (2005) For Space. London: SAGE.

Matejskova, T. and Antonsich, M. (eds) (2015) Governing through Diversity: Migration Societies in PostMulticulturalist Times. Houndsmills: Palgrave Macmillan (Global diversities).

McConnell, F. (2009) 'Governments-in-Exile: Statehood, Statelessness and the Reconfiguration of Territory and Sovereignty', Geography Compass, 3(5), pp. 1902-1919. doi: 10.1111/j.1749-

8198.2009.00274.x.

Medby, I. A. (2014) 'Arctic state, Arctic nation? Arctic national identity among the post-Cold War generation in Norway', Polar Geography, 37(3), pp. 252-269. doi: 10.1080/1088937X.2014.962643.

Medby, I. A. (2015) 'Big Fish in a Small (Arctic) Pond: Regime Adherence as Status and Arctic State Identity in Norway', in Heininen, L., Exner-Pirot, H., and Plouffe, J. (eds) Arctic Yearbook 2015. Akureyri: Northern Research Forum, pp. 313-326.

Merriman, P. and Jones, R. (2016) 'Nations, Materialities and Affects', Progress in Human Geography, p. 0309132516649453 . doi: 10.1177/0309132516649453.

Mitchell, T. (1991) 'The Limits of the State: Beyond Statist Approaches and Their Critics', The American Political Science Review, 85(1), pp. 77-96. doi: 10.2307/1962879.

Mitchell, T. (2006) 'Society, Economy, and the State Effect [1999]', in Sharma, A. and Gupta, A. (eds) The Anthropology of the State: A reader. Oxford: Wiley-Blackwell (9).

Moisio, S. and Paasi, A. (2013a) 'Beyond State-Centricity: Geopolitics of Changing State Spaces', Geopolitics, 18(2), pp. 255-266. doi: 10.1080/14650045.2012.738729.

Moisio, S. and Paasi, A. (2013b) 'From Geopolitical to Geoeconomic? The Changing Political Rationalities of State Space’, Geopolitics, 18(2), pp. 267-283. doi: 10.1080/14650045.2012.723287.

Mountz, A. (2003) 'Human Smuggling, the Transnational Imaginary, and Everyday Geographies of the Nation-State', Antipode, 35(3), pp. 622-644. doi: 10.1111/1467-8330.00342.

Mountz, A. (2004) 'Embodying the Nation-State: Canada's response to human smuggling', Political Geography, 23(3), pp. 323-345. doi: 10.1016/j.polgeo.2003.12.017. 
Medby, I.A. (2018) 'Articulating state identity: 'Peopling' the Arctic state', Political Geography 62, pp. 116 -

125, DOI: $10.1016 /$ j.polgeo.2017.10.008.

Mountz, A. (2013) 'Political Geography I: Reconfiguring geographies of sovereignty', Progress in Human Geography, 37(6), pp. 829-841. doi: 10.1177/0309132513479076.

Nyman, E. (2012) 'Understanding the Arctic: Three popular media views on the north', Political Geography, 31(6), pp. 399-401. doi: 10.1016/j.polgeo.2012.01.004.

Ohmae, K. (1990) The Borderless World: Power and Strategy in the Interlinked Economy. Ex-library edition. New York: Ballinger Pub Co.

Paasi, A. (2015) 'Dancing on the graves: Independence, hot/banal nationalism and the mobilization of memory', Political Geography. doi: 10.1016/j.polgeo.2015.07.005.

Pain, R. (2009) 'Globalized fear? Towards an emotional geopolitics', Progress in Human Geography, 33(4), pp. 466-486. doi: 10.1177/0309132508104994.

Painter, J. (2006) 'Prosaic Geographies of Stateness', Political Geography, 25(7), pp. 752-774. doi: 10.1016/j.polgeo.2006.07.004.

Painter, J. and Jeffrey, A. (2009) Political Geography: An introduction to space and power. Los Angeles, LA: SAGE.

Peck, J. (2001) 'Neoliberalizing States: Thin policies/hard outcomes', Progress in Human Geography, 25(3), pp. 445-455.

Pile, S. and Thrift, N. (eds) (1995) Mapping the Subject: Geographies of Cultural Transformation. London; New York: Routledge.

Powell, R. C. and Dodds, K. (eds) (2014) Polar Geopolitics?: Knowledges, Resources and Legal Regimes. Cheltenham: Edward Elgar.

Pykett, J., Jupp, E. and Smith, F. M. (2016) Emotional States. Routledge. doi: 10.4324/9781315579252.

Sassen, S. (1996) Losing Control?: Sovereignty in an Age of Globalization. New York: Columbia University Press.

Sassen, S. (2013) 'When Territory Deborders Territoriality', Territory, Politics, Governance, 1(1), pp. 21-45. doi: $10.1080 / 21622671.2013 .769895$.

Scott, J. (1999) Seeing Like a State: How Certain Schemes to Improve the Human Condition Have Failed. New Ed edition. New Haven, Conn.: Yale University Press.

Shadian, J. M. (2012) The politics of Arctic sovereignty: oil, ice and Inuit governance. London: Routledge.

Sharma, A. and Gupta, A. (eds) (2006) The anthropology of the state: a reader. Oxford: Blackwell (Blackwell readers in anthropology, 9). 
Medby, I.A. (2018) 'Articulating state identity: 'Peopling' the Arctic state', Political Geography 62, pp. 116-

125, DOI: 10.1016/j.polgeo.2017.10.008.

Sharp, J. (2009) 'Geography and gender: what belongs to feminist geography? Emotion, power and change', Progress in Human Geography, 33(1), pp. 74-80. doi: 10.1177/0309132508090440.

Sharp, J. P. (1993) 'Publishing American Identity: Popular Geopolitics, Myth and the Reader's Digest', Political Geography, 12(6), pp. 491-503.

Shields, R. (1991) Places on the Margin: Alternative Geographies of Modernity. New York: Routledge.

Sparke, M. (2005) In the Space of Theory: Postfoundational geographies of the nation-state. Minneapolis:

University of Minnesota Press.

Squire, R. (2016) 'Rock, Water, Air and Fire: Foregrounding the elements in the Gibraltar-Spain dispute', Environment and Planning D: Society and Space, 34(3), pp. 545-563. doi: 10.1177/0263775815623277.

Steinberg, P. E., Bruun, J. M. and Medby, I. A. (2014) 'Covering Kiruna: A natural experiment in Arctic awareness’, Polar Geography, 37(4), pp. 273-297. doi: 10.1080/1088937X.2014.978409.

Steinberg, P. E., Tasch, J. and Gerhardt, H. (2015) Contesting the Arctic: Politics and Imaginaries in the Circumpolar North. London: I.B.Tauris.

Strandsbjerg, J. (2012) 'Cartopolitics, Geopolitics and Boundaries in the Arctic', Geopolitics, 17(4), pp. 818-842. doi: 10.1080/14650045.2012.660581.

Taylor, P. J. (2003) 'The State as a Container: Territoriality in the Modern World-System', in Brenner, N. et al. (eds) State/Space: A reader. Malden, MA: Blackwell, pp. 101-114.

Thongchai, W. (1997) Siam Mapped: A history of the geo-body of a nation. Honolulu: University of Hawaii Press.

Walker, R. B. J. (1993) Inside/Outside: International Relations as Political Theory. Cambridge: Cambridge University Press (Cambridge studies in international relations, 24).

Williams, L. (2010) 'Telling an Arctic Tale: Arctic Discourses in Canadian Foreign Policy', in Ryall, A., Schimanski, J., and Wærp, H. H. (eds) Arctic discourses. Newcastle-upon-Tyne: Cambridge Scholars Publishing, p. $240+258$.

Williams, L. (2011) 'Canada, the Arctic, and Post-National Identity in the Circumpolar World', The Northern Review, 33(Spring 2011), pp. 113-131.

Wilson Rowe, E. (2013) 'A Dangerous Space? Unpacking state and media discourses on the Arctic', Polar Geography, 36(3), pp. 232-244. doi: 10.1080/1088937X.2012.724461.

Wilson Rowe, E. (2014) 'Arctic Hierarchies? Norway, status and the high north', Polar Record, 50(1), pp. 72-79. doi: 10.1017/S003224741200054X. 
Medby, I.A. (2018) 'Articulating state identity: 'Peopling' the Arctic state', Political Geography 62, pp. 116 -

125, DOI: $10.1016 /$ j.polgeo.2017.10.008.

Woon, C. Y. (2014) 'China, Canada and Framings of Arctic Geopolitics', in Powell, R. C. and Dodds, K. (eds) Polar Geopolitics?: Knowledges, Resources and Legal Regimes. Cheltenham: Edward Elgar, pp. 166-182.

Yaeger, P. (ed.) (1996) The Geography of Identity. Ann Arbor: University of Michigan Press (Ratio).

\section{Endnotes}

${ }^{1}$ Please see Supplementary Material for a map that illustrates both state borders and the Arctic Circle (Ahlenius, 2016).

${ }^{2}$ Specifically, the United Nations Convention on the Law of the Sea (UNCLOS). All eight states have confirmed their adherence (and except the USA, ratified it), and consequently the submission and processing of claims have happened quickly through the last decades, leaving the Arctic region as a space of states.

${ }^{3}$ The Arctic Council is, in brief, an inter-governmental organisation made up of the eight states with territorial claims north of the Arctic Circle (66³3'39”). It is a consensus-based body with no formal decision-making capabilities. It is, however, an important norm-setter and forum for interaction (e.g. Graczyk and Koivurova, 2014; Graczyk et al., 2017).

${ }^{4}$ Please see Supplementary Material; however, confidentiality means that no further identifiable details on individual respondents may be disclosed. 